\title{
Diyabette Hiperglisemi Kaynaklı Oksidatif Stresin Moleküler Mekanizması
}

\author{
The Molecular Mechanism of Hyperglycemia Induced Oxidative Stress in Diabetes
}

\author{
Emine Koçyiğit ${ }^{1}$, Makbule Gezmen Karadağ ${ }^{2}$
}

Geliş tarihi/Received: 29.10.2020 • Kabul tarihi/Accepted: 30.11.2020

\section{ÖZET}

Diyabet tüm dünyada görülme sıklığı giderek artan kronik endokrin bir metabolizma bozukluğudur. Diyabetin ve komplikasyonlarının gelişiminden, artan kan glukoz düzeyinin sonucu olarak ortaya çıkan oksidatif stres sorumlu tutulmaktadır. Organizma oksidan moleküller ve onları ortadan kaldıran antioksidan savunma sistemi arasındaki dengeyi korumaya eğilimlidir. Ancak reaktif oksijen ve nitrojen türlerinin üretimi ve nötralizasyonu arasındaki dengenin bozulup, antioksidan kapasitenin yetersiz kalması sonucu oksidatif stres ortaya çıkmaktadır. Diyabette gelişen hiperglisemiye bağlı olarak glikoliz, hekzosamin, polyol gibi çeşitli metabolik yolakların diyabetli bireylerde aşırı aktivite gösterdiği ve prooksidatif süreci başlattığı belirtilmektedir. Bu metabolik yolaklarda üretilen ürünler tek başına oksidasyonu arttırabildiği gibi diğer yolaklar ve ara ürünlerle de etkileşime girerek oksidatif dengeyi bozmaktadır. Bu derlemede diyabette hiperglisemiye bağlı gelişen oksidatif stresin moleküler düzeydeki nedenleri özetlenmiştir.

Anahtar kelimeler: Reaktif oksijen türleri, hiperglisemi, oksidatif stres, diyabet

\begin{abstract}
Diabetes is a chronic endocrine metabolic disorder that is increasingly common all over the world. Oxidative stress as a result of increased blood glucose levels is held responsible for the development of diabetes and complications. The organism tends to maintain the balance between oxidant molecules and the antioxidant defense system that eliminates them. However, oxidative stress occurs as the balance between the production and neutralization of reactive oxygen and nitrogen species has deteriorated, and insufficient antioxidant capacity. It is stated that various metabolic pathways such as glycolysis, hexosamine and polyol due to hyperglycemia developing in diabetes show excessive activity and initiate the prooxidative process in individuals with diabetes. The products produced in these metabolic pathways alone can increase oxidation, as well as interfere with other pathways and intermediates, disrupting the oxidative balance. In this review, molecular causes of oxidative stress due to hyperglycemia in diabetes are summarized.
\end{abstract}

Keywords: Reactive oxygen species, hyperglycemia, oxidative stress, diabetes

\footnotetext{
* Bu makale, "Diyabette Oksidatif Stresin Moleküler Mekanizması” başlğ̆ıyla 10.10.2019-12.10.2019 tarihinde Ankara'da düzenlenen 2. Uluslararası Sağlıklı Beslenme Kongresi, Endokrin Hastalıklar Kongresi'nde poster bildiri olarak sunulmuştur.

1. İletişim/Correspondence: Gazi Üniversitesi Sağlık Bilimleri Fakültesi Beslenme ve Diyetetik Bölümü, Ankara, Türkiye

E-posta: kocyigitem@gmail.com • ำ https://orcid.org/0000-0002-9459-9557

2. Gazi Üniversitesi Sağllk Bilimleri Fakültesi Beslenme ve Diyetetik Bölümü, Ankara, Türkiye • ๑ https://orcid.org/0000-0003-3202-3250
} 


\section{GíRiş}

Diyabet (DM), insülin eksikliği veya insülin kullanım bozukluğu veya her ikisinin bir arada görüldüğü, organizmada karbonhidrat, yağ ve protein metabolizmasına etki eden hiperglisemi ile karakterize metabolik bir hastalıktır. Diyabete bağlı gelişen kronik hiperglisemi, sinirler, göz, böbrek, kalp ve damarlarda uzun dönem hasarlara, fonksiyon bozukluklarına ve kayıplara neden olmaktadır. Diyabet dünya genelinde ve ülkemizde görülme sıklığı giderek artış gösteren kronik, endokrin metabolik hastalıklar arasında yer almaktadır. Beslenme, nüfus artışı, kentleşmenin getirdiği yaşam tarzı değişikleri, obezite ve fiziksel inaktivite bu artışın başlıca nedenleri olarak değerlendirilmektedir (1). Uluslararası Diyabet Federasyonu'nun (International Diabetes Federation-IDF) son raporunda dünyada 463 milyon DM'li birey bulunduğu bildirilmekte, 2030 yılında bu sayının 578 milyona ulaşacağı tahmin edilmektedir. Ayrıca dünyada DM görülme sıklığı \%9.3 olarak belirtilmiştir (2). Ülkemizde 2010 yılında yapılan Türkiye Diyabet, Hipertansiyon, Obezite ve Endokrinolojik Hastalıklar Prevalans Çalışması-II (TURDEP II) sonuçlarına göre hastalığın görülme sıklığı 20 yaş üstü yetişkinlerde \%13.7 olarak saptanmıştır (3). Türkiye Kronik Hastalıklar ve Risk Faktörleri Sıklığı Çalışması-2013 verilerinde ise DM sıklığı 15 ve üzeri yaş grubunda \%11, 20 yaş ve üzeri grupta \%12.3 ve 35-79 yaş grubunda \%17.5 olarak bulunmuştur (4).

Diyabetin patogenezinde insülinin tamamen veya kısmi eksikliğine bağlı ortaya çıkan hiperglisemi tablosu yer almaktadır. Yapılan çalışmalar özellikle hiperglisemi sonucu artan serbest radikallerin oluşturduğu oksidatif stresin, DM ve DM'ye bağlı komplikasyonların gelişimine neden olduğunu ve lipid peroksidasyonunu önemli derecede arttırdığını göstermiştir $(5,6)$. Normal fizyolojik koşullarda reaktif oksijen ve nitrojen türlerinin (ROS ve RNS) oluşumu ve onları ortadan kaldıran endojen antioksidan savunma sistemi arasındaki homeostatik denge korunmaktadır. Enfeksiyon, hastalıklar, toksinler, beslenmeye bağlı gelişen sorunlar gibi pek çok etken hücrede ROS ve RNS oluşumunu tetiklemekte, bu durum oksidatif stresle sonuçlanmaktadır (7). Oksidatif stres DM'nin yanısıra kardiyovasküler hastalıklar, nörolojik hastalıklar, astım, romatolojik hastalıklar, kanser ve yaşlanma dahil olmak üzere birçok hastalığın gelişiminde esas neden olarak görülmektedir $(8,9)$.

$\mathrm{Bu}$ derlemede, DM'de hiperlisemi nedeniyle gelişen oksidatifstresmoleküler düzeydeincelenerekoksidatif stresin oluşum basamakları değerlendirilmiştir.

\section{Oksidatif Stres}

Hücrenin iç ortamı enfeksiyonlar, toksinler, hastalıklar ya da beslenme dengesizlikleri tarafından bozulduğunda; hücrenin oksijen tüketimini azaltabilmesi için mitokondri elektron akışını kendinden uzaklaştırarak ROS ve RNS’leri oluşturmaktadır. Bu “oksidatifkalkan”, çevreden gelen toksik patojen ya da kimyasalların hücreye alımını azaltmak ya da hücrenin apoptozis ile öldürülmesi ve komşu hücrelere yayılmasının önlenmesi için bir savunma mekanizması olarak görev yapmaktadır. $\mathrm{Bu}$ doğrultuda organizmada ROS ve RNS oluşumu strese fizyolojik bir cevaptır (10).

Oksidatif stres, ROS ve RNS'nin aşırı üretimi veya yetersiz giderimi ile yüksek seviyelere ulaştığı durum olarak tanımlanmaktadır (11). Yüksek reaktif özellik gösteren bu biyomoleküller protein, lipit ve deoksiribo nükleik asite (DNA) zarar vermekte, endotelyal ve mitokondriyal hasara sebep olarak DM, kardiyovasküler hastalıklar, kanser gibi pek çok hastalık için risk faktörü oluşturmaktadır $(12,13)$.

\section{Reaktif Oksijen ve Nitrojen Türlerinin Oluşumu}

Serbest radikaller, kısa ömürlü bir ya da daha fazla eşlenmemiş elektron içeren reaktif kimyasallar olarak tanımlanmaktadır (14). Hücre farklılaşması ve göçünün normal sürecinde kendiliğinden oluşmakta, eşlenmemiş elektronları ile hücreler arasında rahatlıkla geçebilmekte, bu geçiş hücrenin ve hücrede var olan moleküllerin oksidasyonu 
ile sonuçlanmaktadır. Genel olarak tüm serbest radikaller çok kararsız ve reaktiftir $(14,15)$.

Süperoksit $\left(\mathrm{O}_{2}^{-}\right)$, hidroksil $\left(\mathrm{OH}^{-}\right)$, peroksil $\left(\mathrm{RO}_{2}^{-}\right)$, hidroperoksil $\left(\mathrm{HRO}_{2}^{-}\right)$radikalleri reaktif oksijen türlerini; nitrik oksit (NO) ve nitrojen dioksit $\left(\mathrm{NO}_{2}{ }^{-}\right)$reaktif nitrojen türlerini oluşturmaktadır. Hidrojen peroksit $\left(\mathrm{H}_{2} \mathrm{O}_{2}\right)$, ozon $\left(\mathrm{O}_{3}\right)$, singlet oksijen $\left({ }^{1} \mathrm{O}_{2}\right)$, hipokloröz asit ( $\left.\mathrm{HOCl}\right)$, nitrik asit $\left(\mathrm{HNO}_{2}\right)$, peroksinitrit (ONOO), dinitrojen trioksit $\left(\mathrm{N}_{2} \mathrm{O}_{3}\right)$ ve lipit peroksit (LOOH) ise nonradikal reaktif türler olarak tanımlanmaktadır (16). Serbest radikaller diğer nonradikal reaktif türlere kolay bir şekilde dönüşebilmekte, patolojik ve fizyolojik durumlarda serbest radikal reaksiyonlarına yol açabilmektedir (17).

Hücresel düzeyde ROS’lar temel olarak iki mekanizma ile oluşurken: nikotinamid adenin dinükleotit fosfat hidrojen (NADPH) oksidaz ve mitokondriyal fonksiyon; RNS'ler nitrik oksit sentez yolağı ile üretilmektedir. Reaktif oksijen ve nitrojen türleri Tablo 1'de gösterilmiştir.

\section{Mitokondriyal Elektron Transport Zinciri ve NADPH Oksidaz}

Pek çok dokuda ROS temel olarak hücre mitokondrisinde oluşmaktadır (16). Mitokondri içinde elektron transport zinciri sitokrom c oksidaz seviyesinde elektronik indirgenme ile oksijen moleküllerinden su üretmektedir. Bu elektronlar başlangıçta nikotinamid adenin dinükleotid $(\mathrm{NADH})$ ve flavin adenin dinükleotidin $\left(\mathrm{FADH}_{2}\right)$ sirasiyla indirgenmesi sonucu sitokrom c oksidaza ulaşmaktadır. Elektron transfer sürecinde az bir miktar (0.2-\%2) elektron komplex I ve komplex III'de kaybolur, kaybolan elektronlar oksijen moleküllerinin süperoksit radikallerine indirgenmesine neden olmaktadır $(18,19)$.

Oksidazlar, moleküler oksijeni kullanarak redoks tepkimelerini katalizleyen enzim grubudur. İnsan vücudunda ksantin oksidaz, glukoz oksidaz, monoamin oksidaz, sitokrom p450 oksidaz ve NADPH oksidaz gibi çok sayıda oksidaz bulunmaktadır $(20,21)$. NADPH oksidaz biyosentez reaksiyonları için gereken enerjiyi azaltmakta ve aynı zamanda NADPH oksidaz için elektron verici substrat görevi görmekte; hücre içinde süperoksit ve/veya hidrojen peroksitin oluştuğu temel biyokimyasal reaksiyonu kataliz etmektedir (22).

\section{Nitrik Oksit Sentaz}

Organizmada üç izoforma sahip olan NO-, nitrik oksit sentaz enziminin aktivitesiyle oluşmaktadır. $\mathrm{Bu}$ izoformlar, nöronlarda ekspre edilen nöral form (nNOS/ NOS-I), damarların düz kaslarında, hepatositlerde, makrofajlarda, nöroendokrin dokularda ekspre edilen indüklenen form (iNOS/NOSII) ve endotelyal hücrelerde ekspre edilen endotelyal form (eNOS/NOS-III)'dur (23).

Nitrik oksit sentaz, oksijen ve NADPH varlığında, L-arjininin guanidin nitrojenini okside ederek L-sitrülin ve $\mathrm{NO}^{-}$oluşumunu kataliz etmektedir (24). NO- kolayca membrandan geçebilmekte, farklı

Tablo 1. Reaktif oksijen ve nitrojen türleri

\begin{tabular}{ll}
\hline Nonradikal reaktif türler & Serbest radikaller \\
\hline Hidrojen peroksit $\left(\mathrm{H}_{2} \mathrm{O}_{2}\right)$ & Süperoksit (O2-) \\
Ozon $\left(\mathrm{O}_{3}\right)$ & Hidroksil (OH-) \\
Singlet oksijen $\left(\mathrm{O}_{2}\right)$ & Peroksil (RO2-) \\
Hipokloröz asit $(\mathrm{HOCl})$ & Hidroperoksil (HRO2-) \\
Nitrik asit $\left(\mathrm{HNO}_{2}\right)$ & Nitrik oksit (NO-) \\
Peroksinitrit $\left(\mathrm{ONOO}^{-}\right)$ & Nitrojen dioksit (NO2-) \\
Dinitrojen trioksit $\left(\mathrm{N}_{2} \mathrm{O}_{3}\right)$ & \\
Lipit peroksit $(\mathrm{LOOH})$ & \\
\hline
\end{tabular}


hücresel olaylarda etkili olabilmekte, aynı zamanda $\mathrm{O}_{2}^{-}$ile kolayca reaksiyona girerek peroksinitrite dönüşebilmektedir. Peroksinitrit oldukça aktif bir serbest radikaldir (25). NO' sentezi Şekil 1'de gösterilmiştir.

\section{Diyabette Oksidatif Stresin Patofizyolojisi}

DM'li bireylerde fiziksel aktivitede azalma, yetersiz ve dengesiz beslenme, bozulmuş glukoz toleransı, inflamasyon, hipoksi ve genetik faktörler kan glukoz düzeyini artırarak oksidatif strese yol açan başlıca faktörlerdir (26). Bunlara ek olarak DM’lilerin sağlıklı bireylere kıyasla antioksidan savunma sistemi aktivitelerindeki azalma hücresel düzeyde oksidatif dengenin bozulmasıyla sonuçlanmaktadır (27). Hiperglisemi sonucu artan ROS/RNS ile protein, lipit ve nükleik asitlerin nonenzimatik glikasyonuyla oluşan ileri glikasyon son ürünleri (advanced glycation end products-AGE) pankreatik hücreler, karaciğer, kas ve adipoz doku hücrelerinin disfonksiyonuna sebep olarak, nöropati, nefropati, retinopati ve vasküler hastalıklar gibi DM’ye bağlı gelişen ikincil komplikasyonların oluşumunu tetiklemekte, insülin sekresyonunu bozarak bireylerde DM'nin ilerleyişine neden olmaktadir (28). Oksidatif stresin endotel hücreler, pankreas ve periferal hücreler üzerine etkisi Şekil 2'de belirtilmiştir.

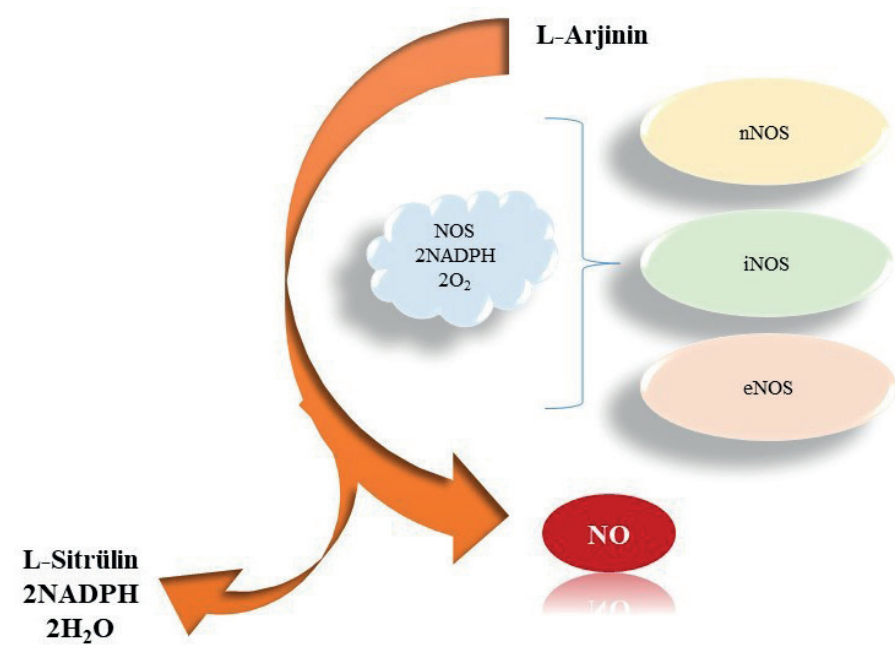

Şekil 1. Nitrik oksit sentezi (24)

NADPH: nikotinamid adenin dinükleotit fosfat hidrojen, NO: nitrik oksit, NOS: nitrik oksit sentaz, eNOS: endotelyal nitrik oksit sentaz, iNOS: indüklenebilir nitrik oksit sentaz, nNOS: endotelyal nöronal nitrik oksit sentaz, $\mathrm{H}_{2} \mathrm{O}: \mathrm{su}, \mathrm{O}_{2}$ : oksijen
DM'de hiperglisemi kaynaklı oksidatif stres oluşumu çeşitli mekanizmalar aracılığıyla gerçekleşmektedir. Bu çalışmada oksidatif strese yol açan mekanizmalar ayrıntılı bir şekilde incelenmiş ve altı başlık altında toplanmıştır. Bu başlıklar; glikoliz yolağı, diaçilgliserol oluşumu ve protein kinaz aktivasyonu, AGE oluşumu, hekzosamin yolağı, polyol yolağı ve hiperglisemi kaynaklı oksidatif stres olarak belirtilmiştir.

\section{Glikoliz Yolağı}

Sağlıklı hücrede glikolizin son ürünü olan pirüvat, krebs döngüsüne katılmaktadır. Krebs döngüsünde üretilen NADH ve $\mathrm{FADH}_{2}$ elektron transport zincirinde okside olarak ortamda adenozin trifosfat (ATP) sentezi için gerekli proton konsantrasyonunu arttırmaktadır. Bu sırada oluşan süperoksit anyonları antioksidan savunma sistemi tarafindan etkisiz hale getirilmektedir (29). Hiperglisemi durumunda, süperoksitin aşırı üretimi antioksidan sistemi baskllayarak oksidatif stres ve oksidatif strese bağlı DNA hasarına neden olmaktadır. Gelişen DNA hasarını gidermek için aktifleşen poli-ADP-riboz polimeraz-1 enzimi (PARP-1), gliseraldehit 3-fosfat dehidrogenazı (GAPDH) inhibe ederek; gliseraldehit 3-fosfat (GAP), fruktoz-6-fosfat (F-6-P) ve glukoz-6-fosfat (G-6-P) ve glukoz seviyelerinin artışına neden olmaktadır. Hücre içinde bu moleküllerin birikimi AGE ve protein kinaz C (PKC) gibi prooksidan yolakları aktive etmektedir. Aynı zamanda F-6-P ve glukoz seviyelerinin artışı hücrede heksozamin ve polyol yolaklarının etkinliğini artırmaktadır. GAP birikimi de hidrojen peroksit oluşumuna neden olarak oksidatif stresi teşvik etmektedir $(30,31)$.

\section{Diaçilgliserol Oluşumu ve Protein Kinaz Aktivasyonu}

Protein kinaz C, çeşitli fizyolojik ve patolojik tepkimelerde rol alan serin/treonin kinazların bir üyesidir (32). Hücresel sinyalin sağlanmasında rol alan 11 izoformu bulunan PKC, hiperglisemik koşullarda PARP-1 ve GAPDH'ı inhibe ederek, GAP birikimi ile diaçilgliserolün (DAG) aşırı üretimine neden olmaktadır. Diaçilgliserol, PKC’yi uyararak, 


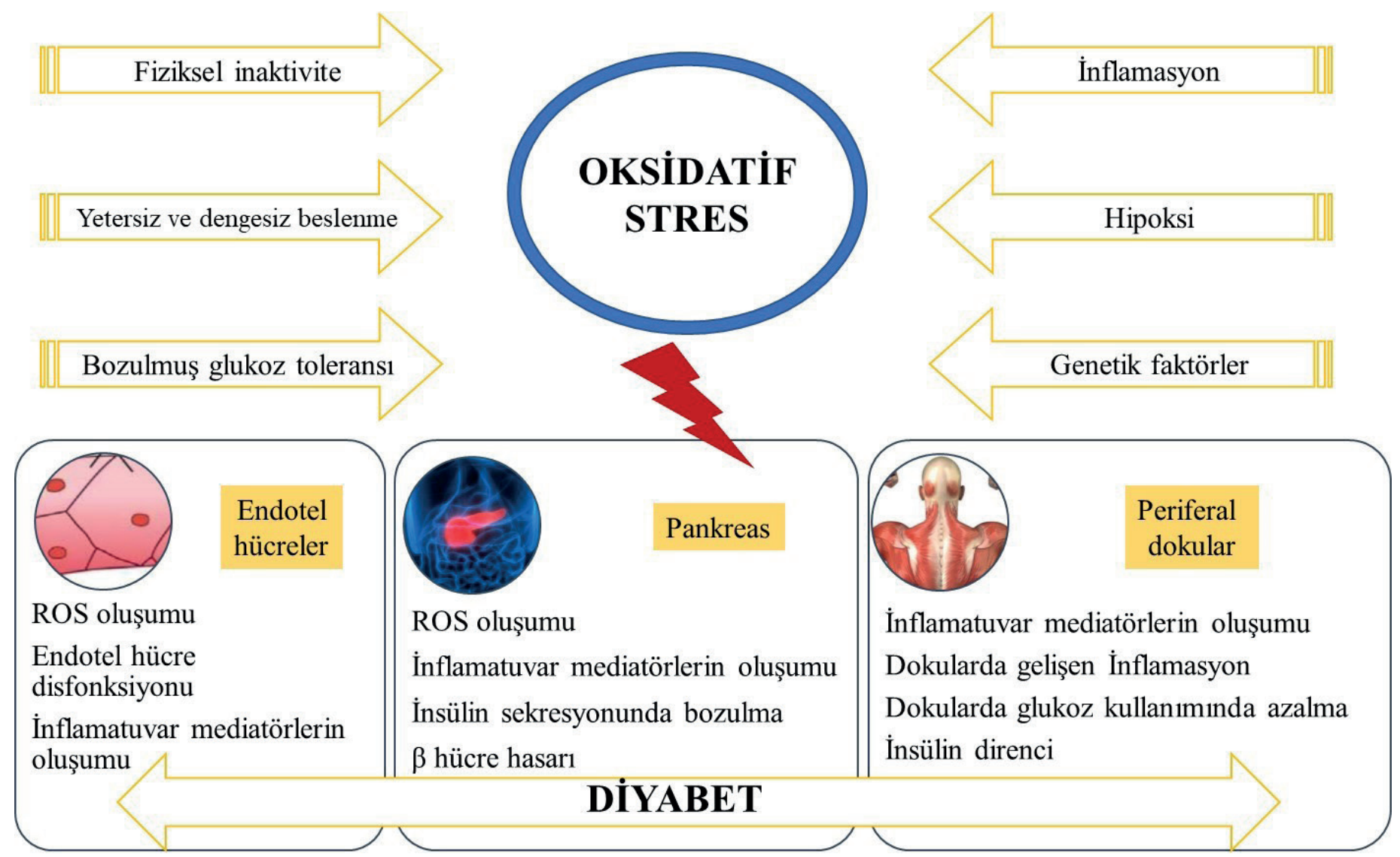

Şekil 2. Oksidatif stresin endotel hücreler, pankreas ve periferal hücreler üzerine etkisi (26)

ROS oluşumunu tetikleyen oksijenaz enzimleri ve NADPH oksidazı aktive etmektedir. Buna ek olarak AGE oluşumu PKC aktivasyonuna etki eden bir diğer faktördür (33).

\section{AGE Oluşumu}

İleri glikasyon son ürünleri proteinler, lipoproteinler ve/veya nükleik asitlerde bulunan azotlu gruplar ile indirgeyici şekerlerin karbonil grupları arasında nonenzimatik glikasyon sonucu oluşan heterojen bileşiklerdir (34). Glukozun otooksidasyonu ile glioksal, gliseraldehit-3-P'ın nonenzimatik fosforilasyonu ile metilglioksal ve amadori ürünlerinin yıkımı ile 3-deoksi glukozon oluşmakta, bu ürünler ekstrasellüler matriksin protein, lipit ve DNA kompenentleri ile reaksiyona girerek AGE'leri oluşturmaktadır. AGE'ler oluşumunu takiben AGER1, AGER2, AGER3 ve RAGE reseptörlerine bağlanmakta ya da hücre dışı matris bileşenleri ile anormal etkileşime girerek direkt olarak ROS oluşumunu indüklerken, aynı zamanda PKC'yi aktive ederek de oksidatif strese yol açmaktadır. Diyabette AGE oluşumu hiperglisemik durumunda görülen klinik bir tablodur (35).

\section{Hekzosamin Yolağı}

Amino şekerlerin sentezlendiği hekzosamin yolağı, hız sinırlayıcı enzim glutamin fruktoz-6-fosfat amino transferaz (GFAT) tarafından F-6-P'nin glukozamin6-fosfata dönüşümünü sağlayan hız sınırlayıcı GFAT enziminin aktivitesi ile gerçekleşen bir dizi reaksiyonu içermektedir. Glukozamin-6-fosfat, üridin difosfat-N asetilglukozamine (UDP-GlcNAc) aktive edilir. Üridin difosfat-N asetilglukozamin, protein ve lipitlerin glikosil zincirlerinin oluşumunda önemli metabolik bir bileşendir. Aynı zamanda proteinlerin translasyon sonrasındaki modifikasyonu için kullanılmaktadır (36).

Normoglisemik bireylerde glikoliz basamağında oluşan fruktoz-6-P'ın az bir kısmı hekzosamin yolağında metabolize olmakta ve bu bireylerde 
reaksiyonu kataliz eden glukozamin-fruktoz amidotransferaz (GFAT) enzim aktivitesi düşük ya da normal düzeydedir. Hiperglisemik koşullarda aşırı miktarda biriken F-6-P, GFAT enzim aktivitesini stimüle etmektedir. Glukozaminfruktoz amidotransferaz enzim aktivisindeki artısın UDP-GlcNAc seviyelerini arttırmasinı takiben O-Glukozamin-N-Asetil transferaz enzimi aktive olmaktadır. Bu aktivasyon ile dönüştürücü büyüme faktörü TGFa ve $\beta$ 'nın ekspresyonunu stimüle olarak mezengial hücre mitogenezini inhibe etmekte, kolajen matriksin proliferasyonunu uyarmakta ve membran kalınlaşmasına neden olmaktadır. Hekzosamin yolağında meydana gelen bu değişiklik özellikle diyabetik nefropati ile ilişkili tutulmaktadır (36).

\section{Polyol Yolağı}

Polyol yolağı, glukozun bir polialkol olan sorbitole dönüşümünden sorumlu aldoz redüktaz enziminin kataliz ettiği bir dizi reaksiyondan oluşmaktadır. Sağlıklı hücrelerde aldoz redüktaz enziminin glukoza affinitesi düşüktür. Ancak hiperglisemi varlığında, kanda yüksek miktarda bulunan glukoz polyol yolağına girerek sorbitol oluşumuna neden olmaktadır. Aldoz redüktaz enziminin aktivitesi için NADPH gereklidir (37). NADPH, redoks tepkimelerinde görevli glutatyon peroksidaz ve glutatyon redüktazın kofaktörü olarak görev yapmakta, bu enzimler antioksidan savunmada etkili glutatyonun aktif formda kalmasını sağlamaktadır. NAPDH'ın sorbitol üretiminde kullanımına bağlı olarak azalan glutatyon aktivitesi antioksidan sistemi baskllayarak oksidatif strese yol açmakta, bunun yanında artan sorbitol, fruktoza dönüşerek GAP ve dihidroksi aseton fosfat (DHAP) birikimi ile sonuçlanmaktadır. Bu birikimin indüklediği metilglioksal oluşumu ve PKC aktivasyonu yolu ile de oksidatif stres tetiklenmektedir $(37,38)$. DM'de hiperglisemi kaynaklı oksidatif stresin moleküler mekanizmaları Şekil 3’te verilmiştir.

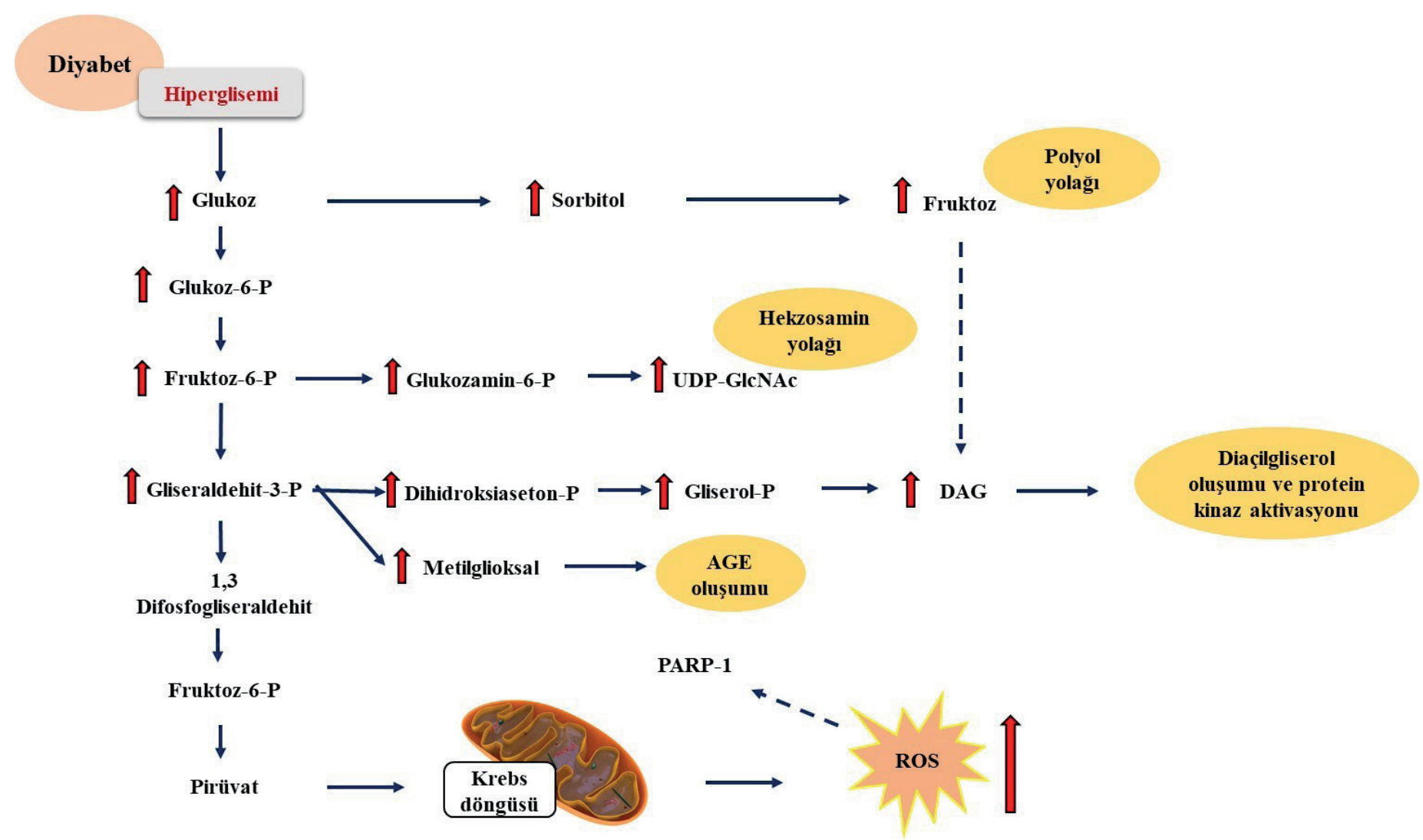

Şekil 3. Diyabette hiperglisemi kaynaklı oksidatif stresin moleküler mekanizmaları (39) AGE: ileri glikasyon son ürünleri, DAG: diaçilgliserol, P: fosfat, PARP-1: poli-ADP-riboz polimeraz-1, ROS: reaktif oksijen türleri, UDP-GlcNAc: üridin difosfatNasetilglukozamin 


\section{Hiperglisemi Kaynaklı Oksidatif Stres}

İnsülin sekresyonu ve aktivitesinde meydana gelen hasarlar oksidatif stresle ilişkili tutulmaktadır. Kan glukoz düzeyi arttığında hücre içine giren glukoz, glikoliz reaksiyonlarını tamamlayarak, krebs döngüsü ve elektron transport zinciri ile ortamda bulunan ATP miktarını artırmaktadır. Artan ATP, potasyumun hücre dışına çıkışını engellemekte, oluşan depolarizasyon kalsiyumun hücre içine girmesini sağlamakta ve veziküllerden insülin salınımını başlatmaktadır (39). Hiperglisemi nedeniyle oluşan oksidatif ortamda, eşlenmemiş protein 2 (UCP-2) aktive olmakta ve hücre içerisinde ATP/ADP oranı azalmaktadır. Bu durum insülin sekresyonu, insülin salınımı ve insülin aktivasyonunu inhibe ederek, insülinin etkin olduğu gen ekspresyonu, hücre proliferasyonu ve diferansiyonu gibi hayati önem taşıyan olayları olumsuz etkilemektedir. Bunlara ek olarak hücre içine glukozun alınmasını sağlayan glukoz reseptörlerinin yüzeyel yerleşimi bozulmakta, insülinin etkin regüle ettiği anabolik ve katabolik reaksiyonlar hasar görmektedir $(39,40)$.

\section{SONUÇ VE ÖNERİLER}

Diyabet yüksek kan glukoz düzeyi sonucu oksidatif stresin arttığı endokrin bir hastalıktır. Artan oksidatif stres DM ve DM'ye bağlı gelişen komplikasyonların ortaya çıkışında büyük rol oynamaktadır. Hücresel düzeyde DM ile ilişkili oksidatif stresin temelinde gliseraldehit-3-P birikimi yer alırken, AGE ve polyollerin üretimi, diaçilgliserol oluşumu ve PKC aktivasyonu, glukozun otooksidasyonu ile heksozamin yolağı aktivasyonundaki artış da hiperglisemi kaynaklı oksidatif stresi arttıran faktörler arasında yer almaktadır. Oksidatif stresi önlemek amacıyla diyette antioksidan içeriği yüksek sebze ve meyveler, yağlı tohumlar, tahillar gibi besinlere yer vermekle birlikte düzenli egzersiz yapılması büyük önem taşımaktadır. Özellikle antioksidan savunma sisteminde görevli enzimlerin kofaktörü olan çinko, selenyum, bakır gibi mineraller ve bu minerallerin besinsel kaynakları, enzim aktivitesini artırabilmektedir. Aynı zamanda A, C, E gibi antioksidan vitaminler ile polifenollerden zengin besinleri içeren bir diyet serbest radikallerin ortamdan uzaklaştırılarak oksidatif dengenin korunmasında etkili olacaktır.

Çıkar çatışması - Conflict of interest: Yazarlar çıkar çatışması olmadığını beyan ederler. - The authors declare that they have no conflict of interest.

\section{KAYNAKLAR}

1. American Diabetes Association. Standards of medical care in diabetes-2019 Abridged for primary care providers. Diabetes Care. 2019;42 (Suppl 1):14-80.

2. International Diabetes Federation (IDF). IDF Diabetes Atlas (9th ed) 2019. Available at: http://www. diabetesatlas.org/ Accessed: September 3, 2020.

3. Satman I, Omer B, Tutuncu Y, Kalaca S, Gedik S, Dinccag $\mathrm{N}$, et al. Twelve-year trends in the prevalence and risk factors of diabetes and prediabetes in Turkish adults. Eur J Epidemiol. 2013;28(2):169-80.

4. Türkiye Kronik Hastalıklar ve Risk Faktörleri Sıklığ 1 Çalışması-2013, Sağlık Bakanlığı Yayın No: 909, Ankara, 2013.

5. Abudawood M, Tabassum H, Almaarik B, Aljohi A. Interrelationship between oxidative stress, DNA damage and cancer risk in diabetes (Type 2) in Riyadh, KSA. Saudi J Biol Sci. 2020;27(1):177-83.

6. Heidari F, Rabizadeh S, Rajab A, Heidari F, Mouodi $\mathrm{M}$, Mirmiranpour $\mathrm{H}$, et al. Advanced glycation endproducts and advanced oxidation protein products levels are correlates of duration of type 2 diabetes. Life Sci. 2020;260:118422.

7. Poljšak B, Fink R. The protective role of antioxidants in the defence against ROS/RNS-mediated environmental pollution. Oxid Med Cell Longev. 2014;2014:671539.

8. Liguori I, Russo G, Curcio F, Bulli G, Aran L, Della-Morte $\mathrm{D}$, et al. Oxidative stress, aging, and diseases. Clin Interv Aging. 2018;13:757-72.

9. Poprac P, Jomova K, Simunkova M, Kollar V, Rhodes CJ, Valko M. Targeting free radicals in oxidative stress-related human diseases. Trends Pharmacol Sci. 2017;38(7):592-607.

10. Naviaux RK. Oxidative shielding or oxidative stress? J Pharmacol Exp Ther. 2012;342(3):608-18.

11. Johansen JS, Harris AK, Rychly DJ, Ergul A. Oxidative stress and the use of antioxidants in diabetes: Linking basic science to clinical practice. Cardiovasc Diabetol. 2005;4(1):5.

12. An X, Sun X, Yang X, Liu D, Hou Y, Chen H, et al. Oxidative stress promotes ventilator-induced lung injury through activating NLRP3 inflammasome and TRPM2 channel. 
Artif Cells Nanomed Biotechnol. 2019;47(1):3448-55.

13. Neelofar K, Arif Z, Arafat MY, Alam K, Ahmad J. A study on correlation between oxidative stress parameters and inflammatory markers in type 2 diabetic patients with kidney dysfunction in north Indian population. J Cell Biochem. 2019;120(4):4892-902.

14. Halliwell B, Gutteridge JM. Oxygen: boon yet baneintroducing oxygen toxicity and reactive species. Free radicals in biology and medicine. 5th ed. USA: Oxford University Press; 2015. 1-25 p.

15. Valko M, Leibfritz D, Moncol J, Cronin MT, Mazur M, Telser J. Free radicals and antioxidants in normal physiological functions and human disease. J Biochem Cell Biol. 2007;39(1):44-84.

16. Wang J, Wang S. Reactive species in advanced oxidation processes: Formation, identification and reaction. Chem Eng J. 2020:126158.

17. Preiser JC. Oxidative stress. JPEN J Parenter Enteral Nutr. 2012;36(2):147-54.

18. Quinlan CL, Gerencser AA, Treberg JR, Brand MD. The mechanism of superoxide production by the antimycin-inhibited mitochondrial Q-cycle. J Biol Chem. 2011;286(36):31361-72.

19. Bleier L, Dröse S. Superoxide generation by complex III: From mechanistic rationales to functional consequences. Biochim Biophys Acta Biomembr. 2013;1827(11-12):1320-31.

20. Rasmussen M, Abdellaoui S, Minteer SD. Enzymatic biofuel cells: 30 years of critical advancements. Biosens Bioelectron. 2016;76:91-102.

21. Schröder K. NADPH oxidases in bone homeostasis and osteoporosis. Cell Mol Life Sci. 2015;72(1):25-38.

22. Macit S, Akbulut G. Diabetes Mellitus ve Oksidatif Stres. Bes Diy Der. 2015;43(1):59-65.

23. Gantner BN, LaFond KM, Bonini MG. Nitric oxide in cellular adaptation and disease. Redox Biology. 2020:101550.

24. Vannini F, Kashfi K, Nath N. The dual role of iNOS in cancer. Redox Biol. 2015;6:334-43.

25. Rochette L, Zeller M, Cottin Y, Vergely C. Diabetes, oxidative stress and therapeutic strategies. Biochim Biophys Acta Biomembr. 2014;1840(9):2709-29.

26. Rehman K, Akash MSH. Mechanism of generation of oxidative stress and pathophysiology of type 2 diabetes mellitus: How are they interlinked? J Cell Biochem. 2017;118(11):3577-85.

27. Rains JL, Jain SK. Oxidative stress, insulin signaling, and diabetes. Free Radic Biol Med. 2011;50(5):567-75.

28. Tiwari BK, Pandey KB, Abidi A, Rizvi SI. Markers of oxidative stress during diabetes mellitus. J Biomark. 2013;2013.

29. Makino A, Scott B, Dillmann W. Mitochondrial fragmentation and superoxide anion. production in coronary endothelial cells from a mouse model of type 1 diabetes. Diabetologia. 2010;53(8):1783-94.

30. Du X, Matsumura T, Edelstein D, Rossetti L, Zsengellér Z, Szabó C, et al. Inhibition of GAPDH activity by poly (ADPribose) polymerase activates three major pathways of hyperglycemic damage in endothelial cells. J Clin Investig. 2003;112(7):1049-57.

31. Easterday A, Keil N, Subramaniam R. Mechanism of inhibition of glyceraldehyde-3-phosphate dehydrogenase activity by glucose. The FASEB Journal. 2007;21(6):A1015-A1015.

32. Steinberg SF. Structural basis of protein kinase $\mathrm{C}$ isoform function. Physiol Rev. 2008;88(4):1341-78.

33. Massart J, Zierath JR. Role of diacylglycerol kinases in glucose and energy homeostasis. Trends Endocrinol Metab. 2019;30(9):603-17.

34. Parmaksiz I. Advanced glycation end-products in complications of diabetes mellitus. Marmara Med J. 2011;24:141-8.

35. Ighodaro OM. Molecular pathways associated with oxidative stress in diabetes mellitus. Biomed Pharmacother. 2018;108:656-62.

36. Beyer AM, Weihrauch D. Hexosamine pathway activation and O-linked-N-acetylglucosamine: Novel mediators of endothelial dysfunction in hyperglycemia and diabetes. Vascul Pharmacol. 2012;56(3-4):113.

37. Rabbani N, Thornalley PJ. Glycation-and/or Polyol Pathway-Inducing Complications. Huhtaniemi I, editor. 2nd ed. Cambridge: Massachusetts, Academic Press; 2018. 170-179 p.

38. Pole A, Dimri M, Dimri GP. Oxidative stress, cellular senescence and ageing. AIMS Molecular Science 2016;3(3):300-24.

39. Yuan T, Yang T, Chen H, Fu D, Hu Y, Wang J, et al. New insights into oxidative stress and inflammation during diabetes mellitus-accelerated atherosclerosis. Redox Biol. 2019;20:247-60.

40. Matschinsky FM, Wilson DF. The central role of glucokinase in glucose homeostasis: A perspective 50 years after demonstrating the presence of the enzyme in islets of Langerhans. Front Physiol. 2019;10:148. 